\title{
Takdir Dalam Islam (Suatu Kajian Tematik)
}

\author{
Iril Admizal, M.A. \\ Institut Agama Islam Negeri Kerinci \\ iriladmizal7@gmail.com
}

\begin{abstract}
Qadha is a problem that has been discussed since the time of the Prophet, friend, Tabi' in and until now. The issue of fate is very interesting to discuss, because there are several sects that view qadha differently. The first group says that qadha is a decree of Allah which cannot be contested, including human actions, there is already a provision of Allah. The second group argues that qadha is not the absolute will of Allah. However, Allah gave power to humans and humans were given the freedom to control it. So what determines human qadha is himself depending on how a person uses the power given by Allah. And the third Group takes the opinion that qadha can be in the form of God's absolute decree and it can also be in the form of power given to bumans and humans themselves who direct that power. To better understand the problem of qadha more deeply, the writer understands the verses in the al-quran and sees the opinions of the tafsir scholars then packs them in the form of a thematic method, so that they can meet a problem solving point. From the results of the research that the author did, there were 133 qadha words in the al-Qur'an with various finished words. Then the authors see from the language dictionary it turns out that the meaning of the word qadha means measuring, grading or measuring so that we can understand that qadha is the limit, size, content and provisions that Allah has given to bumans. So it can be concluded that qadha is not an absolute provision of Allah, but qadha that occurs in humans has a law of causality or cause and effect, and in the law of cause and effect also applies God's inayah (belp).
\end{abstract}

Keywords: Qadha, Actions, Human

Abstrak. Takdir atau qadha merupakan masalah yang telah dibahas sejak zaman Nabi, Sahabat, Tabi'in dan sampai sekarang. Permasalahan takdir sangat menarik untuk dibahas, karena ada beberapa sekte yang memandang berbeda tentang takdir. golongan pertama mengatakan bahwa takdir adalah ketetapan Allah yang tidak bisa diganggu gugat, termasuk perbuatan manusia, sudah ada ketetapan Allah. Golongan kedua berpendapat yang dimaksud takdir adalah bukan kehendak Allah secara mutlak. Tetapi, Allah memberikan daya kepada manusia dan manusia diberikan kebebasan untuk mengendalikannya. Maka yang menentukan takdir manusia itu adalah dirinya sendiri tergantung bagaimana seseorang itu menggunakan daya yang diberikan Allah. Dan golongan ketiga mengambil pendapat, bahwa takdir itu bisa berbentuk ketetapan Allah secara mutlak dan bisa juga dalam bentuk daya yang diberikan kepada manusia dan manusia itu sendiri yang mengarahkan daya tersebut. Untuk lebih memahami permasalah takdir lebih mendalam maka penulis memahami dari ayat-ayat yang ada dalam al-qur'an dan melihat pendapat dari ulama tafsir kemudian mengemasnya dalam bentuk metode tematik, sehingga bisa bertemu dengan titik pemecahan masalah. Dari hasil penelitian yang penulis lakukan terdapat sebanyak 133 kata qadha dalam al-Qur'an dengan berbagai kata jadinya. Kemudian 
penulis lihat dari kamus bahasa ternyata pengertian dari kata qadha adalah berarti mengukur, memberi kadar atau ukuran sehingga dapat kita pahami bahwa qadha adalah batas, ukuran, kadar dan ketentuan yang telah diberikan Allah kepada manusia. sehingga dapat disimpulkan takdir bukan ketentuan Allah secara mutlak tetapi takdir yang terjadi pada manusia ada hukum kausalitas atau sebab akibat, dan di dalam hukum sebab akibat berlaku juga inayah (pertolongan) Allah.

Kata Kunci: Qadha, Perbuatan, Manusia

\section{PENDAHULUAN}

Agama Islam yang ditegakkan oleh Nabi Muhammad saw. Dan umatnya memiliki ajaran-ajaran sebagai pedoman hidup di dunia ini bagi umat manusia. Ajaran-ajarannya itu dapat dibagi kepada dua bagian, (Dahlan, 2001, hlm. 136) yaitu: pertama, sebagian yang berada di bidang aqidah (keyakinan), dan keuda, bagian yang berada dibidang 'amal (perbuatan). Ajaran yang berada dala bidang aqidah dimaksudkan untuk mendorong dan membimbing umat manusia mengembangkan diri menuju kesempurnaan pandangan (teoritis), yakni kesempurnaan pengetahuan, pemahaman, aqidah, atau iman. Sedangkan ajaran yang berada dalam amal (perbuatan) dimaksudkan untuk mendorong dan membimbing umat manusia demi mengembangkan amal-amal sehingga tercapai kesempurnaan amali (Dahlan, 2001, hlm. 136).

Masalah takdir merupakan salah satu keyakinan atau 'itikad terpenting yang banyak mendapat perhatian baik ulama mutaqaddimin maupun ulama mutaakhirin. Ada banyak kesimpulan tentang takdir diantaranya Islam mengajarkan falsafah "fatalism" artinya manusia berserah diri kepada apa yang terjadi pada dirinya, tanpa ada usaha untuk merubah dari suatu keadaan ke keadaan lain yang lebih baik. Karena semua usaha dan ikhtiar tidak ada gunanya.

Ada yang berpendapat bahawa ajaran tentang takdir itu membuat orang jadi malas untuk berusaha, karena setelah mempelajari dan mendalami tentang takdir orang menjadi bersifat "menanti keuntungan" saja menunggu nasib baik. Yang sangat berbahaya ketika berhubungan dengan perbuatan 
manusia, takdir dan ikhtiar dipahami secara salah, sehingga berdampak pada perbuatan yang hanya menuruti hawa nafsunya, berbuat dosa dan maksiat, karena mereka berkeyakinan bahwa perbuatan yang mereka lakukan sudah merupakan takdir dari Tuhan (A. Jaiz, 1421, hlm. 2).

Sebagian orang menjadikan dalih untuk melakukan perbuatan maksiat dan perbuatan-perbuatan tercela lainnya. Mereka melemparkan kesalahan kepada takdir dan pelanggaran mereka terhadap syariat agama. Sehingga terbentuklah golongan yang menentang pendapat seperti itu dan menolak adanya takdir. Manusia bebas melakukan apa saja, karena Allah telah memberikan keleluasaaan kepada manusia untuk memilih dan memilah apa yang ingin dilakukan.

Tujuan dari penelitian ini adalah untuk meluruskan pemahaman orang-rang Islam tentang takdir. Selama ini pemahaman orang-orang tentang takdir mengacu kepada mazhab atau aliran yang mereka pegang. Dengan adanya penelitian ini akan megembangkan wawasan tentang takdir yang berlandaskan al-Qur'an.

Pembahasan tentang takdir bukanlah sesuatu yang baru dalam Islam, cikal bakal perpecahan Islam dalam berbagai aliran itupun salah satunya disebabkan adanya perbedaan pemahaman terhadap ayat-ayat yang membicarakan tentang takdir. Sudah banyak para peneliti dan ilmuan-ilmuan Islam yang membahas tentang takdir salah satunya, penelitian yang dilakukan oleh Djaya cahyadi yang berjudul Takdir dalam pandangan Fakhr al-Din alRazhi. (Cahyadi, 2011) dalam tulisannya ia menyimpulkan bahwa al-Razhi berpandangan bahwa takdir itu telah ditentukan sejak azali.

Selain penelitian di atas ada juga penelitian yang dilakukan oleh Arnesih tentan Konsep Takdir dalam al-Qur'an (Arnesih, 2017) penelitian ini lebih menitik beratkan konsep takdir berdasarkan turunnya ayat al-qur'an sehingga penelitian ini melihat takdir dari segi waktu. 
Sampai disini penulis memaparkan hasil penelitian terdahulu yang relevan. Dilihat dari penelitian-penelitian yang ada, maka penulis memandang masih perlunya melakukan penelitian yang lebih lanjut tentang takdir, yang khusus membahas tentang hubungan takdir dengan kehendak Allah. Penelitian ini mengambil sumber data primer dari al-Qur'an.

Penelitian ini merupakan library research (penelitian kepustakaan) yang mana sumber-sumber yang menjadi rujukan dalam penelitian ini diambil dari perpustakaan, seperti: buku-buku, artikel-artikel, jurnal-jurnal, dan lain-lain.

Penelitian ini juga menggunakan metode tafsir maudhu'i, metode ini adalah metode yang mengarahkan kepada suatu tema tertentu, lalu mengarahkan pandangan kepada al-Qur'an, dengan cara mengumpulkan ayat-ayat yang berkaitan dengan masalah takdir. Selanjutnya dilakukan penalaran (analisis) terhadap isi kandungan ayat-ayat al-Qur'an. Sambil memperkaya uraian dengan hadis-hadis, pendapat sahabat maupun pendapat ulama, sehingga hasil akhirnya bisa diambil kesimpulan tentang permasalahan takdir.(Shihab, 2013, hlm. 385)

\section{PEMBAHASAN}

\section{Pengertian}

Kata al-qadr (القدر) - يقدر - قدرا secara bahasa berasal dari kata kerja قرر yang berarti kekuasaan, ukuran sesuatu, penentuan, kemuliaan, (Mustafa, 1392, hlm. 718) dan term takdir yang berakar sama dengan al-qadr adalah mashdar dari kata قدر - يقدر - قدر yang berarti penentuan, pengaturan dan penentuan sesuatu. (Mustafa, 1392, hlm. 718) Dalam lisan al-Arab, kata alQadr dan al-Taqdir mempunyai makna yang sama yaitu ketentuan Allah, kedua kata ini sering digunakan dalam makna yang sama yaitu ketentuan Allah. Itulah sebabnya rukun iman yang ke enam yaitu iman kepada al-qadr dalam hadis tentang rukun iman sering diungkapkan iman kepada takdir sekalipun lafaznya tertulis لقدرا. Ulama kenamaan Indonesia M. Quraish Shihab menjelaskan bahwa kata takdir terambil dari kata قدر yang antara lain 
berarti mengukur, memberi kadar atau ukuran, jika anda berkata, Allah telah mentakdirkan demikian, maka itu berarti Allah telah memberi kadar, ukuran, batas tertentu dalam diri, sifat atau kemampuan maksimal pada makhluk-Nya. (Shihab, 1997, hlm. 61) hal senada juga dijelaskan oleh Fatahul Gulen yang menjelaskan takdir adalah sebuah kadar yang proporsional yang ditentukan oleh Allah (Haderi, 2014).

Dalam sebuah jurnal yang ditulis oleh Muh. Dahlan Thalib disebutkan takdir adalah salah satu sifat Allah Swt. Yang bermakna berkuasa atau menetapkan sesuatu, apakah ketetapan itu berbentuk mulia, sempit maupun lapang (Thalib, 2015).

Untuk lebih memperdalam lagi pemahaman tentang takdir, berikut ini penulis paparkan beberapa pengertian takdir menurut ulama.

\section{Al-Jurjaniy}

Al-Qadr adalah keterkaitan kehendak Tuhan dengan segala keadaan baik itu masalah waktu, keadaan zaman tertentu (al-Jurjani, tth, hlm. 174).

\section{Ibn Manzhur}

Qadha dan qadar adalah muwaffiq (mempunyai pengertian sama) dikatakan Tuhanlah yang menentukan (dan bisa juga berarti) apabila sesuatu itu sesuai dengan sesuatu (artinya akan terjadi sesuai dengan kadar ketentuannya). (Ibn Manzur, tth, hlm. 22)

\section{Abu Hanifah}

Qadar adalah penentuan sesuatu dengan martabatnya yang akan diperoleh berupa kebaikan dan kejahatan, manfaat dan mudharat yang meliputi setiap ruang dan waktu, termasuk penentuan, ganjaran dan hukuman. (al-Kufi, tth, hlm. 22)

Dari beberapa definisi di atas, ada dua pendapat yang bisa kita ambil. Pertama, bahwa takdir adalah sesuatu ketentuan yang sudah ditakdirkan Allah sejak azali berlaku bagi semua makhluk ciptaan-Nya. Termasuk apa yang akan didapat dan tidak akan bisa dirubah berupa kebaikan, kejahatan, pahala dan 
siksaan. Kedua, pemahaman tentang takdir lebih mengarah kepada adanya usaha manusia untuk melaksanakan sesuatu perbuatan yang menjadikannya sebab akibat berlakunya takdir itu.

Pemahaman takdir pada versi pertama tidak salah, karena ada hal-hal dalam hidup di luar kemampuan dan nalar manusia untuk menolak dan melakukannya, hanya saja jika pemahaman ini yang diterapkan, maka orang Islam akan memiliki mental dan semangat yang tidak mendorong kreativitas, akan melahirkan sikap fatalistik, yang mana sikap seperti ini akan menyerahkan semua sesuatu kepada nasib yang akan terjadi tanpa ada usaha untuk memperbaiki atau mengubahnya. Orang Islam tidak akan mengalami kemajuan bahkan penurunan karena tidak ada kreativitas yang diciptakan.

Pemahaman dari pengertian yang kedua akan mendorong lahirnya kreativitas, sikap dan perilaku dinamis, karena terjadinya takdir itu terkait dengan kegiatan yang sesuai dengan ketentuannya, mengupayakan sesuatu yang sesuai dengan ketentuan yang akan terjadi menjadi peluang manusia untuk kreatif menentukan cara yang sesuai dalam mengatasi masalah.

\section{Takdir dalam al-Qur'an}

Dalam al-Qur'an kata takdir dalam berbagai bentuk disebut sebanyak 133 kali. (al-Baqi, tth, hlm. 538) Kata qadha dalam berbagai bentuk disebutkan sebanyak 63 kali. Kata qadar dalam berbagai bentuk tidak termasuk bentuk fail, disebut sebanyak 73 kali. (al-Baqi, tth, hlm. 538) Untuk melihat makna dasar pada beberapa surat tersebut, penulis akan mengemukakan beberapa keterangan dari para ahli tafsir. Dalam surah al-Isra':30, Allah berfirman:

"Sesunggubnya Tuhanmu melapangkan rezeki kepada siapa yang dia kehendaki dan menyempitkannya, sesungguhnya dia Maba Mengetahui Lagi Maha Melihat akan hamba-bamba-Nya."

Ayat yang semakna dengan surah al-Isra': 30 terulang sebanyak 10 kali, yaitu dalam QS.al-Ra'du (13):26, al-Nabl (16): 75, al-Isra' (17): 30, al- 
Qashas (27):82, al-Ankabut (29): 62, al-Rum (30): 37, Saba' (34): 36, alZumar(39): 52, al-Syura (42): 12, dan al-Balad (90):5. (al-Baqi, tth, h. 36)

Al-Tabari dalam kitab tafsirnya menjelaskan bahwa Allah SWT menyampaikan kepada Nabi Muhammad SAW, sesungguhnya Tuhanmu melapangkan rezeki bagi siapa yang dikehendaki dari hamba-hamba-Nya, sehingga ada yang menjadi kaya, dan menyempitkan kepada siapa yang dia kehendaki, sehingga menjadi kekurangan dan miskin. (al-Thabari, 1412, h. 342) Jadi makna dari kata al-qadr adalah adanya wewenang Allah dalam mengatur rezeki seseorang, Allah bisa saja melapangkannya dan bisa pula sebaliknya. Pendapat ini senada dengan Fakhr al-Din al-Razi. (al-Razi, 1405, h. 17)

Quraish shihab berpendapat bahwa ayat di atas menunjukkan rezeki disediakan oleh Allah SWT untuk setiap hamba-Nya untuk mencukupi masing-masing yang bersangkutan.(Shihab, 2002, hlm. 455) Di satu sisi manusia dianjurkan untuk berusaha semaksimal mungkin guna memperoleh rezeki, dan menerimanya dengan ikhlas dan rasa puas disertai dengan keyakinan inilah yang terbaik. Disisi lain ia harus yakin bahwa apa yang gagal diperolehnya setelah berusaha secara maksimal, hendaknya meyakini bahwa hal inilah yang terbaik bagi dirinya. Oleh karena itu tidak perlu melakukan perbuatan yang bertentangan dengan tuntunan dan perintah Allah untuk memperoleh rezeki. Karena apa yang diusahakan dalam memperoleh rezeki dengan jalan yang tidak sesuai dengan aturan Islam maka akan merugikan dirinya sendiri.

Ayat ini juga bisa dipahami sebagai perintah Allah, untuk senantiasa berusaha dengan tangan (hasil keringat) sendiri, dan setelah itu bersikap tengah-tengah (hemat) dalam hidup serta mencela kebakhilan dan melarang bersifat boros dan berlebih-lebihan.

Untuk lebih memahami lagi makna qadr disini penulis akan memaparkan surah al-Qamar (54): 12 
"Dan kami jadikan bumi memancarkan mata air-mata air, maka bertemulah air-air itu untuk suatu urusan yang sunggub telah ditetapkan."

Maksud dari pertemuan air bumi dan air langit, dan suatu pertemuan itu tidak mungkin terjadi bila hanya satu melainkan terjadi sekurangkurangnya dua benda atau lebih. Memang kata الماء bisa bermakna jamak dan bisa bermakna tunggal. dan pada ayat di atas bentuknya tunggal dan maknanya jamak. (al-Razi, 1405, hlm. 68) Dengan memperhatikan kata qadr pada ayat tersebut maka hal itu menunjukkan tentang proses terjadinya sesuatu pada bentuk tertentu, dalam hal ini pertemuan antara air langit dan air bumi yang berjalan sesuai dengan hukum kausalitas, artinya terjadinya sesuatu dikarenakan adanya sesuatu hal yang diperbuat. Berkaitan dengan takdir dapat kita pahami bahwa terjadinya suatu takdir pada seseorang dikarenakan perbuatan yang dilakukan sebelumnya.

Dalam mengkaji ayat-ayat qauliyah dan ayat-ayat kauniyah, setidaknya menurut Komaruddin Hidayat terdapat tiga macam takdir yang dikenal manusia. (Hidayat, 1996, hlm. 120) Pertama, adalah takdir yang terjadi pada penomena alam seperti dalam surah al-An'am (6): 96

"Dia menyingsingkan pagi dan menjadikan malam untuke beristirabat, dan (menjadikan) matahari dan bulan untuk perbitungan. Itulab ketentuan Allah yang Maba Perkasa lagi Maha Mengetabui."

Yaitu hukum atau ketentuan Allah yang mengikat perilaku alam yang bersifat objektif sehingga waktu serta hukum kausalitas alam mudah dipahami oleh manusia. Respon waktu dari mekanisme hukum alam ini relatif pendek sehingga hasil dan efeknya mudah serta cepat diketahui oleh manusia. Contoh yang mudah dipahami adalah seperti obat-obatan yang diberikan kepada manusia. Adanya takdir Allah yang berlaku objektif dari obat ini terjadilah hukum kausalitas atau hukum sebab akibat.

Kedua, takdir yang berkenaan dengan hukum sosial (sunnatullab) yang berlaku dengan melibatkan manusia hadir di dalamnya. Dalam ayat al-Qur'an 
takdir yang berbentuk sunnatullah ini sering diisyaratkan dengan bentuk pertanyaan seperti, "Apakah kamu sekalian tidak belajar dari perilaku kaum sebelum kamu yang senantiasa membuat kerusakan di bumi?" nada pertanyaan semacam ini sering diulang dalam al-Qur'an yang mengisyaratkan bahwa takdir Allah itu objektif. Artinya, nasib jatuh bangun suatu kaum itu memiliki rasionalitas tersendiri yang dipahami oleh generasi setelahnya. Karena adanya hukum sosial objektif inilah maka kita selalu mengenal yang namanya ilmu sejarah, sosiologi dan juga psikologi. Waktu respon dari sunnatullah ini relatif lebih panjang ketimbang takdir yang berlaku pada hukum alam. Lebih dari itu hasilnya juga tidak sejelas pada hukum alam karena manusia yang mengamati ikut hadir dan terlibat di dalamnya. Itulah sebabnya barangkali ilmu humaniora itu sering dikenal dengan istilah soft science sedangkan ilmu alam disebut hard science.

Ketiga, adalah takdir dalam pengertian kepastian Allah, yang berlaku tetapi waktu responnya lebih jauh lagi, yaitu efeknya baru diketahui setelah di alam akhirat nanti. Ketika di dunia efek dari hubungan sebab akibatnya belum berakhir, sehingga harus dibuktikan nanti di akhirat. Takdir Allah yang ketiga ini bisa disikapi dengan iman, karena selama kita masih di dunia efeknya belum bisa dibuktikan. Sementara informasinya lalu didasarkan pada berita kitab suci. Takdir seperti ini kadang al-Qur'an menggunakan dengan istilah qadha bahwa nasib orang di akhirat nanti akan ditentukan oleh apa yang diperbuat selama hidup di dunia. Bagi siapa yang berbuat amal kebaikan maka akan memperoleh kenikmatan di akhirat, dan bagi siapa yang berbuat kejahatan maka ia pun akan mendapat kesengsaraan.

Dari ketiga bentuk takdir yang telah penulis paparkan di atas dapat kita ambil kesimpulan takdir pada dasarnya adalah merupakan semacam hukum sebab akibat yang berlaku secara pasti, yang operasionalnya di bawah kontrol Allah SWT. 
Ayat-ayat yang menggunakan kata qadha menggambarkan bahwa penciptaan alam semesta dan segala isinya serta segala isinya serta segala ketentuannya yang berlaku atasnya adalah qadha Allah melalui hukum yang adil, Allah juga memberlakukannya di akhirat. Dengan demikian segala suatu yang terjadi di alam semesta adalah qadha juga dikaitkan dengan kata qadha manusia, seperti ketika Nabi Musa menetapkan waktu untuk kembali ke Mesir.

Seperti kata qadha, kata qadar juga dikaitkan dengan segala ciptaan Allah baik itu yang di langit maupun yang di bumi sehingga masing-masing telah ditetapkan ukurannya sesuai dengan fungsinya yang kemudian disebut sebagai takdir Allah atau sunnatullah. Bentuk ketentuan seperti api membakar, dinginnya air, burung bisa terbang, kemampuan manusia terletak pada fisik, akal dan rohaninya dan lain sebagainya mulai yang terbesar sampai yang terkecil. Terkait dengan adanya kekuasaan Allah dalam meluaskan dan menyempitkan rezeki, maka manusia tidak mempunyai kekuasaan mutlak atas usahanya.

Kesimpulan yang dapat ditarik dari paparan di atas adalah, segala yang manjud dan terjadi di alam semesta ini adalah karena qadba Allah yang masing-masing telah ditentukan kadar atau takdirnya. Manusia tidak mempunyai kekuasaan mutlak atas segala usahanya, tetapi takdir Allah yang berlaku secara mutlak.

Berbeda dengan Kamaruddin Hidayat, Ahmad Sanusi mengelompokkan qadar Tuhan menjadi dua yaitu: (1) Qadar mubram, yaitu ketentuan Tuhan kepada manusia, alam dan peristiwa yang mesti terjadi dan tidak dapat dielakkan. (2) Qadar mu'allaq, ialah ketentuan Tuahan yang masih dapat berubah. (Sanusi, tth, hlm. 14)

Qadar mubram adalah suatu qadar yang terjadi pada alam semesta sedangkan qadar mu'allaq mengatur tingkah laku atau perbuatan-perbuatan 
manusia. Dari sudut inilah manusia harus percaya kepada segala ketentuanketentuan yang telah diatur oleh Allah.

Pembagian takdir kepada muallaq, jangan dijadikan sebuah belenggu yang mengekang nasib manusia, manusia adalah makhluk yang mempunyai akal, dari akal itu manusia bebas memilih dan bertindak dan memilih alternatif terbaik bagi kepentingan dirinya.

Hubungan manusia dengan takdir Allah, sebagaimana yang telah dijelaskan di atas, maka sesuai dengan peran dan fungsi manusia itu sendiri sebagai khalifah Tuhan di bumi, ia memikul beban berat dan mulia. Oleh karena itu, diberikan akal dan kemampuan fisik yang tangguh, dalam QS 'Abasa: 18-19 Allah menjelaskan:

"Dari apakah Allah menciptakannya? Dari setetes mani, Allah menciptakannya lalu menentukannya."

Kata فقر pada ayat di atas menjelaskan tentang penciptaan organ manusia yang begitu lengkap, tujuan diberikannya kesempurnaan kepada manusia supaya bisa memenuhi kebutuhan hidupnya di dunia, sejak dari asal kejadianya hingga akhir hayat, dengan kata lain, hubungan manusia dengan takdir Tuhan mengandung unsur ikhtiyari, tidak pasif. Kerena di dalam perbuatan manusia yang berbentuk ikhtiyari, terjadilah hubungan yang aktif yang terwujud dalam sikap, gairah manusia untuk tidak sekedar hidup secara alamiah, tatapi membawa paham dinamika, ia tidak sekedar menerima apa adanya, melainkan berusaha mengubah dan memperbaiki kehidupan diri dari lingkungan. Dalam bentuk yang lebih jauh lagi, hubungan aktif ini di wujudkan dalam bentuk usaha dan keinginan manusia yang mempunyai tanggung jawab dalam menentukan sikap dan pilihannya, sebab manusia kelak akan dimintai tanggung jawabnya dihadapan Allah. 
Dalam hal itu pula al-Qur'an menjelaskan persoalan pertanggung jawaban adalah bersifat pribadi sebagaimana yang dijelaskan Allah dalam QS. Al-Fathir (35): 18

"Dan orang yang berdosa tidak akan memikul dosa orang lain. dan jika seseorang yang berat dosanya memanggil (orang lain) untuk. memikul dosanya itu tiadalah akan dipikulkan untuknya sedikitpun meskipun (yang dipanggilnya itu) kaum kerabatnya. Sesunggubnya yang dapat kamu beri peringatan Hanya orang-orang yang takut kepada azab Tubannya (sekalipun) mereka tidak. melihat-Nya dan mereka mendirikan sembahyang. dan barangsiapa yang mensucikan dirinya, Sesunggubnya ia mensucikan diri untuk kebaikan dirinya sendiri. dan kepada Allablab kembali(mu).”

Berdasarkan ayat di atas maka qadar dan tanggung jawab manusia sebanding dengan kemampuan yang dimiliki secara perorangan, sehingga beban di luar tanggung jawabnya tidak dapat di terima. (Sanusi, tth, hlm. 15) Dengan demikian, hubungan manusia dengan takdir, seharusnya dimanifestasikan dalam bentuk peran dan fungsi serta penyesuaian diri secara aktif dan kreatif dalam rangka pengembangan amanat Tuhan.

Dari dua yang mengemukakan pembagian takdir, secara zhahir kelihatan berbeda. Tetapi, pada prinsipnya mempunyai kesamaan. Terutama tentang takdir manusia, takdir manusia bukan semata-mata kehendak dari Allah. Tetapi, mempunyai hubungan kausalitas atau sebab akibat, pendapat ini dikuatkan oleh Ahmad Sanusi yang menjelaskan tentang pemberian akal kepada manusia. akal yang diberikan kepada manusia itu merupakan hak pribadi dalam penggunaannya. Dan pertanggung jawabannya juga secara perorangan.

\section{Hubungan Takdir dengan Sunnatullah}

Allah SWT menggunakan kata pencipta dengan kata khalaqa dan katakata jadinya. Dalam kamus disebutka bahwa kata khalqa mempunyai pengertian dasar yaitu memberikan ukuran kepada sesuatu (taqdir al-syay) dan melicinkan sesuatu (malasah al-syay .(Zakariya, 1969, hlm. 213). Kata tersebut 
digunakan juga untuk menunjukkan penciptaan tanpa asal, atau contoh sesuai dengan QS. al-An'am (6): 73

"Dan Dialah yang menciptakan langit dan bumi dengan benar. dan benarlab perkataan-Nya di waktu Dia mengatakan: "Jadilah, lalu terjadilab", dan di tangan-Nyalah segala kekuasaan di waktu sangkakala ditiup. Dia mengetahui yang ghaib dan yang nampak. dan dialah yang Maba Bijaksana lagi Maha Mengetahui."

Diartikan demikian itu karena sesuai dengan QS.al-Baqarah (2): 117 "Allab pencipta langit dan bumi, dan bila Dia berkehendak (untuk menciptakan) sesuatu, maka (cukuplab) Dia banya mengatakan kepadanya: "Jadilab!" lalu jadilab ia."

Pemakaian kata khalaqa dalam pengertian menciptakan hanya dimiliki oleh Allah SWT hal ini dipertegas agar dapat membedakan antara Allah dengan selain-Nya. Sunnatullah fi khaliqatibi (sistem Allah dalam mengelola penciptaan-Nya) sebagaimana al-Qur'an adalah bersifat konstan, tidak pernah mengalami pergantian dan tidak mengenal perubahan. Sebagaimana dijelaskan oleh Allah dalam QS. Fatih (35): 43

"Karena kesombongan (mereka) di muka bumi dan karena rencana (mereka) yang jahat. rencana yang jahat itu tidak akan menimpa selain orang yang merencanakannya sendiri. tiadalah yang mereka nanti-nantikan melainkan (berlakunya) sunnah (Allah yang Telah berlaku) kepada orang-orang yang terdahulu. Maka sekali-kali kamu tidak akan mendapat penggantian bagi sunnah Allab, dan sekali-kali tidak (pula) akan menemui penyimpangan bagi sunnah Allab itu."

Muthahhari menyebutkan bahwa sunnatullah tidak akan berubah sebagaimana berubahnya hukum-hukum yang relatif yang dapat ditambahkan atau dikurangi, kemudian bagian tersebut direvisi tanpa harus menghapus prinsip tersebut. (Muthahhari, 1401, hlm. 22)

Dengan sistem pengolahan yang konstan, maka segenap alam ciptaan ini berproses dengan berjalan secara rutin, obyektif dan eksak, dengan sistem demikian sifatnya berproses, pergeseran atau interaksi yang terjadi adalah 
bersifat otonom. Allah menegaskan bahwa perjalanan segenap alam ciptaan ini bersifat otonom sehingga tidak akan ada siksa atau bencana yang diturunkan tiba-tiba. Lantaran dosa-dosa yang diperbuat manusia. Kalau dosa-dosa yang diperbuat manusia itu menjadi sebab turunnya bencana, maka tidak akan ada makhluk yang selamat dari bencana. Karena terlalu banyak dosa-dosa yang diperbuat manusia.

Demikian bahwa Allah menciptakan segala sesuatu, kemudian pada setiap penciptaan-Nya diletakkan dengan qadar (ukuran) yang bersifat eksak yang dikaitkan dalam hubungan sebab akibat. Hubungan atau interaksi antar sesuatu dengan sesuatu yang lain dengan kadarnya masing-masing yang kemudian melahirkan kualitas atau kejadian tertentu dengan berjalan dan berproses secara otonom. Semua manjud akan mampu dan dapat berjalan secara pasti, obyektif dan terus menerus, di mana satu jenis ciptaan dengan jenis ciptaan yang lain akan saling terkait, saling ketergantungan, sehingga seluruh isi alam ini merupakan satu kesatuan. Maka alam bisa berkemabang secara seimbang (Subhi, 1969, hlm. 113).

Senada dengan pendapat di atas M. Quraish Shihab, mengatakan bahwa peristiwa-peristiwa yang terjadi di alam raya ini, dari sisi kejadiannya, dalam kadar atau ukuran tertentu, pada tempat dan waktu tertentu, dan itulah yang disebut takdir (Shihab, 1997, hlm. 63). Tidak ada sesuatu yang terjadi tanpa takdir, termasuk manusia. Peristiwa-peristiwa tersebut berada dalam pengetahuan dan ketentuan Allah, yang keduanya menurut sementara ulama dapat disimpulakan dalam istilah sunatullah, atau sering salah disebut dengan istilah "hukum-hukum alam" (Shihab, 1997, hlm. 63). Allah SWT dalam mengelola alam ciptaan-Nya bersifat konstan, tidak mengenal perubahan dan tidak pernah mengalami pergantian. Karena sunnatullah bersifat konstan, maka manusia mampu dan dapat melakukan pengamatan atau penelitian, sehingga adanya yang namanya "ilmu pengetahuan". Ilmu pengetahuan dalam kontek ini, tidak lain adalah upaya manusia untuk 
memahami hukum Allah (hukum kausalitas) yang diletakkan pada alam ciptaan-Nya. Oleh karena itu ilmu pengetahuan akan memiliki nilai-nilai kebenaran secara representatip mewakili kepastian hukum-Nya. Sedangkan ilmu pengetahuan yang benar akan sangat bermanfaat bagi kehidupan. Apabila kita memperhatiakn perubahan pada hukum alam, maka perubahan tersebut benar-benar merupakan akibat yang ditimbulkan oleh berubahnya syarat-syarat. Jelas bahwa suatu hukum alam akan berlaku pada lingkuangan syarat tertentu, dan apabila syarat tersebut berubah, maka yang akan berlaku adalah sunsatullah yang lain, dan perubahan itu terkait pula oleh syarat-syarat tertentu. (Muthahhari, 1401, hlm. 110) Dengan demikian, hukum alam itu berubah menurut hukum itu sendiri, tidak dalam pengertian bahwa suatu hukum itu dihapuskan begitu saja lantas diaganti dengan hukum tertentu, begitu terjadi perubahan dalam syarat-syarat hukum tertentu, maka muncullah syarat-syarat yang baru yang memberikan jalan bagi munculnya hukum baru, sehingga yang berlaku adalah hukum alam yang baru itu. Atas dasar itulah, maka alam tidak diatur kecuali oleh hukum yang tetap dan tidak berubah.

Apabila kita melihat orang mati bisa hidup kembali karena mukjizat, maka kejadian tersebut, pada dasarnya memiliki hukum yang mengatur. Seorang manusia yang dilahirkan tanpa ayah, sebagaimana yang terjadi pada Nabi Isa, maka kejadian tersebut pada dasarnya, tidaklah membatalkan sunnatullah, juga tidak membatalkan hukum alam. Perlu diketahui bahwa manusia tidaklah mengetahui seluruh hukum alam. Karena itu ia tidak berhak, apabila melihat suatu kejadian yang tampaknya bertentangan dengan hukum yang ia ketahui, untuk menganggapnya sebagai kejadian yang bertentangan dengan hukum alam, serta membatalkan hukum sebab akiba. (Muthahhari, 1401, h. 110). Suatu yang dipandang sbagai hukum tersebut, dan bukan hukum tersebut itu sendiri. Minsalnya, bahwa hukum wujud itu mengharuskan lahirnya manusia itu selalu dari campuran antara seorang ayah 
dan ibu. Padahal pada hakikatnya ia hanya merupakan sisi luar dari hukum alam itu, dan bukan hukum alam sebenarnya (Muthahhari, 1401, hlm. 110). Dengan begitu kelahiran Nabi Isa tidaklah membatalkan sunatullah, melainkan membatalkan pandangan sisi luar mengenai sunatullah.

Sebagian orang menganalogikan sunnatullah di alam semesta, proses penciptaan, balasan, pahala, kebahagiaan dan penderitaan dengan hukum sosial manusia. Padahal, kenyataan sunnatullah itu mengikuti serangkaian syarat-syarat takwiniyah dan haqiqiyah, dan dipandang sebagai bagian darinya. Adapaun kondisi-kondisi sosial tidak lain hanyalah persoalan-persoalan relatif (itibariyah) yang nilainya dibatasi oleh konvensi sosial manusia. Dengan demikian maka hukum-hukum sosia dapat dipandang mengikuti syarat-syarat relatif dan konvensional. Adapun mengenai persoalan penciptaan, kejadian, balasan, pahala, dan sangsi Allah, tidak mungkin mengikuti syarat-syarat tersebut, tatapi mengikuti syarat-syarat takwiniyah.

Hukum bukanlah suatu yang terpisah, yang sering dikaitkan dengan hal praktik penciptaan, melainkan konsep universal yang ditarik oleh pikiran yang tidak memiliki identitas luar tersendiri. Jadi, yang ada di luar hanyalah hukum sebab akibat, dan ketika derajat wujud dan pikiran menyerap sesuatu yang ada di luar, berarti ia menarik suatu hukum yang universal. Dengan begitu, wujud itu memiliki tingkatan-tingkatan dan masing-masing tingkatan memiliki posisi yang tetap, dan tidak mungkin sebab dari suatu itu akan terlepas dari posisinya sebagai sebab dari sesuatu yang lain. Begitu juga tidak mungkin sesuatu akibat akan terlepas dari posisinya sebagai akibat dari sesuatu yang lain.

\section{Hubungan Takdir dengan Doa dan Tawakkal}

Hakikat Allah menciptakan manusia, tidak mengetahui segala sesuatu. Allah mengajarkan kepada manusia apa yang dilakukannya untuk hidup di dunia ini. Yaitu hal-hal yang mendatangkan kebaikan bagi agama, dunia, aqidah dan amalannya. Allah memberikan kepada manusia kesanggupan 
memahami apa yang Allah bentangkan di alam raya ini, yang menunjukkan kepada wrijud Allah dan kesempurnaan sifat-Nya, dan Allah memberi petunjuk kepada manusia aturan-aturan kebenaran, keadilan dan kebajikan melalui perantaraan Rasul-Nya.

Allah memberikan pula hidayah akal dan fitrah, yang dengan hidayah itu manusia mengetahui jalan-jalan memperoleh penghidupan. Kemudian Allah merahasiakan dari manusia dari segi yang selain dari itu,yakni yang tidak sanggup dijangkau oleh fitrahnya, seperti mengetahui apa yang akan terjadi, apa yang telah ada di atas langit, apa yang ada di bawah bumi, atau sesuatu yang tersirat dalam dada manusia dan didalam rahim ibu, serta segala yang di qadarkan untuknya, baik rezeki maupun ajal (al-Shidqy, 1999, hlm. 12).

Allah telah berkehendak dengan mengikat segala sebab dengan musababnya dan mengistimewakan manusia atas makhluk yang lain, dengan jalan memberikan manusia kehendak yang mendorong kepada kemajuan, atau mundur yang disarankan oleh akal yang dapat membedakan antara yang baik dengan yang buruk. Sekiranya manusia mengetahui apa yang Allah ketahui, apa yang akan dihadapi, baik senang maupun susah, kebahagiaan atau pun kecelakaan, tentulah dia tidak memikirkan sesuatu yang dapat mendatangkan manfaat baginya, atau yang menolak kemudaratan, dan tentulah sebab musabab, lalu hilanglah fungsi akal itu, iradat serta rusaklah kaedah sebab musabab. (al-Shidqy, 1999, hlm. 103) Andaikata kita mengetahui kapan kita meninggal atau kita gugur dalam ujian, tentulah sepanjang masa menjadi bimbang pikiran dengan masalah-masalah itu. Dari sinilah diperlukan adanya pensinkronisasian antara takdir dengan doa, dan tawakkal. Berikut penulis paparkan hubungan takdir dengan doa dan tawakkal: 


\section{Doa}

Doa adalah permohonan hamba kepada Tuhannya, tidak sedikit ayat al-Qur'an yang memerintahkan untuk senantiasa berdoa dan beribadah kepada Allah seperti dalam QS. al-Mu'min (40) 60

"Dan Tubanmu berfirman: "Berdoalab kepada-Ku, niscaya akan Kuperkenankan bagimu. Sesunggubnya orang-orang yang menyombongkan diri dari menyembah-Ku akan masuk neraka Jahannam dalam keadaan bina."

Wujud Allah yang mutlak dan dirasakan oleh jiwa manusia, serta keyakinan adanya hukum-hukum yang ditetapkan-Nya, tidak boleh mengantarkan manusia meninggalkan doa, sebab keberlakuan hukumhukum itu, idak mengakibatkan terbatasnya Allah dari perbuatan dan kebijaksanaan-Nya. (Shihab, 2000, hlm. 96) Dalam penciptaan alam raya ini Allah tidak membuat seperti pabrik yang memproduksi "jam" kemudian membiarkan berjalan secara otomatis di tangan. Tetapi, perlu kita ingat ada namanya sunatullab (hukum-hukum Allah yang mengatur alam raya) dan ada juga inayatullah (pertolongan Allah). Yang tidak kalah dari sunnah-Nya. Inayah itu ditunjukkan kepada orang-orang yang benar-benar berdoa kepadanya. (Shihab, 2000, hlm. 96)

\section{Tawakkal}

Tawakkal berasal dari kata wakala yang artinya menyerahkan, jadi tawakkal kepada Allah artinya, menyerahkan kepada Allah. (al-Afriqi, 1414, hlm. 734) Menurut istilah tawakkal adalah menyerahkan dan menyandarkan diri kepada Allah setelah berusaha serta berpegang teguh kepada-Nya setelah melakukan usaha atau ikhtiar. (al-Dumajiji, 2000, hlm. 3)

Ayat al-Qur'an banyak menjelaskan tentang tawakkal, bahwa manusia harus tawakkal dan tawakkalnya itu harus didahului dengan usaha atau ikhtiar. Seperti QS. al-Anbal (16): 41- 42

'Dan orang-orang yang berbijrah karena Allah sesudah mereka dianiaya, pasti kami akan memberikan tempat yang bagus kepada mereka di dunia. dan 
sesungguhnya pahala di akbirat adalah lebih besar, kalau mereka mengetahui, (Yaitu) orang-orang yang sabar dan banya kepada Tuban saja mereka bertawakkal."

Demikian seseorang muslim yang tawakal sepenuhnya kepada Allah SWT tentu akan senantiasa mengikuti segala bentuk petunjuk-Nya. Maka dalam kontek ini tawakkal tidak berarti pasif. Muslim yang taat mengikuti petunjuk Allah justru akan menjadi dinamis dan aktif, sebab al-Qur'an sendiri yang mengajarkan mukmin agar senantiasa berusaha dan berjuang dengan penuh semangat dalam mengarungi lautan hidup di dunia ini dalam rangka memenuhi hajat hidupnya.

Tawakkal tidak bisa lepas dari konsep kausalitas atau hukum sebab akibat. Setelah melakukan usaha yang maksimal dan di iringi dengan doa, sehingga jalan akhirnya adalah menyerahkan seluruhnya kepada Allah. Muslim wajib yakin akan adanya pertolongan Allah.

\section{PENUTUP}

Pada bagian akhir penulis berusaha mengambil kesimpulankesimpulan sebagai cakupan dari semua bahasan mengenai takdir. Semua ayat al-Qur'an menunjukkan bahwa yang dimaksud dengan takdir adalah undang-undang Allah yang universal yang bergerak di segala bidang, baik pada diri manusia maupun alam semesta. Manusia dianugerahi akal yang diberikan Allah kepadanya, dituntut aktif dan kreatif dalam mewujudkan perbuatannya, karena itu manusia disamping akal yang dimilikinya juga dilengkapi potensi dan daya. Dari sisi ini manusia memiliki kebebasan dan kewenangan memilih serta menentukan jenis perbuatannya yang hendak dilakukan, bahkan dengan kemampuan intelektualnya, ia bebas melakukannya. Namun perlu diingat sejak awal Allah telah memberikan pedoman yang tersurat dalam al-Qur'an.

Takdir menurut al-Qur'an mempunyai kecenderungan kepada konsep manusia produktif dan aktif sehingga diberi peran sangat penting. Ia diberi 
tugas dan tugas itu diwujudkan dalam berbagai bentuk perbuatan. Tugas terwujud karena ia diberi syarat-syarat untuk itu, misalnya anggota badan, akal, pilihan, putusan, daya dan kemampuan.

Dibalik adanya hukum kausalitas perlu diingat ada inayah (pertolongan) Allah yang bisa terjadi pada manusia, orang Islam wajib yakin di setiap perbuatan dan tindakan adanya pertolongan Allah bisa diwujudkan melalui doa. Dan bagian akhir adalah menyerahkan sepenuhnya kepada Allah atau tawakkal.

\section{DAFTAR REFERENSI}

A. Jaiz, H. (1421). Rukun Iman Digoncang. Pustaka al-Naba'. al-Afriqi, J. al-D. M. ibn M. ibn M. (1414). Lisan al-'Arab. Dar al-Fikr. al-Baqi, F. 'Abd. (tth). Al-Mu'jam al-Muharas li al-Fazab al-Qur'an. Dar al-Fikr. al-Dumajiji, A. ibn U. (2000). Rahasia Tawakkal dan Sebab Akibat. Pustaka Azzam.

al-Jurjani, al-S. 'Ali ibn M. (tth). Kitab al-Ta'rifat. Jeddah Haramain.

al-Kufi, A. H. al-N. ibn T. (tth). Syarah Kitab al-Figh al-Akbar. Dar al-Kutub al-Ilmiyah.

al-Razi, F. al-Din. (1405). Tafsir Fakhr al-Razi: Vol. X. Dar al-Fikr.

al-Shidqy, T. M. H. (1999). Sejarah dan Pengantar Ilmu Taubid/Kalam. Pustaka Rizki Putra.

al-Thabari, A. J. M. ibn J. al-Thabari. (1412). Tafsir al-Thabari al-Musamma alJami' al-Bayan fi Ta'wil al-Qur'an: Vol. VIII. Dar al-Kutub al-Ilmiyah.

Arnesih. (2017). Konsep Takdir dalam al-Qur'an. Diya al-Fakar Jurnal Studi alQur'an dan Hadis.

Cahyadi, D. (2011). Takdir Dalam Pandangan Fakhr al-Din al-Raz̧bi.

Dahlan, A. A. (2001). Teologi dan Aqidah dalam Islam. IAIN IB-Press.

Haderi, H. (t.t.). Takdir dan Kebebasan Menurut Fathullab Gulen.

Hidayat, K. (1996). Takdir dan Kebebasan. Paramadina.

Ibn Manzur. (tth). Lisan al-Arab. Dar al-Kutub al-Ilmiyah. 
Mustafa, I. (1392). Al-Ziyad, al-Mu'jam al-Wassith. al-Maktabah al-Islamiyah.

Muthahhari, M. (1401). Al-Adl al-Ilahiy. al-Dar al-Islamiyah li al-Nasyr.

Sanusi, A. (tth). Al-Lu'lu' al-Nadhid fi mas'il al-Tawhid. Batavia Centrum.

Shihab, M. Q. (1997). Wawasan al-Qur'an, Fungsi dan Peran Wabyu dalam Kehidupan Masyarakat. Mizan.

Shihab, M. Q. (2000). Secercah Cahaya Ilabi; Hidup Bersama al-Qur'an. Mizan.

Shihab, M. Q. (2002). Tafsir al-Mishbah Pesan, Kesan dan Keserasian al-Qur'an: Vol. VII. Lentera Hati.

Shihab, M. Q. (2013). Kaidah Tafsir. Lentera Hati.

Subhi, A. M. (1969). Fi 'Im al-Kalam Dirasah Falsafah, al-Mu'tazilah al-Asya'irah al-Syia'h. Dar al-Kutub al-Ilmiyah.

Thalib, Muh. D. (2015). Takdir dan Sunatullah. al-Ishla: Jurnal Pendidikan, 13.

Zakariya, A. H. A. ibn. (1969). Mu'jam Muqayyis al-Lughawi: Vol. II. Mushthafa al-Babi al-Halabi. 